\title{
CYTOTOXIC EFFECTS OF IMIDAZOLIUM IONIC LIQUIDS ON FISH AND HUMAN CELL LINES
}

\author{
Marina CVJETKO, Kristina RADOŠEVIĆ, Andrej TOMICA, Igor SLIVAC, \\ Jasna VORKAPIĆ-FURAČ, and Višnja GAURINA SRČEK \\ Faculty of Food Technology and Biotechnology, University of Zagreb, Zagreb, Croatia \\ Received in July 2011 \\ CrossChecked in October 2011 \\ Accepted in December 2011
}

\begin{abstract}
Ionic liquids bring a promise of a wide range of "green" applications that could replace conventional volatile solvents. However, before these applications become large-scale, their toxicity needs to be investigated in order to predict the impact on human health and environment. In this study we assessed the cytotoxicity of imidazolium ionic liquids (in the concentrations between $0.1 \mathrm{mmol} \mathrm{L}^{-1}$ and $10 \mathrm{mmol} \mathrm{L}^{-1}$ ) in the ovarian fish cell line $\mathrm{CCO}$ and the human tumour cell line HeLa using the MTT cell viability assay. Our results showed that the most cytotoxic ionic liquid was 1-n-butyl-3-methylimidazolium bis(trifluoro methylsulphonyl)imide, [BMIM] $\left[\mathrm{Tf}_{2} \mathrm{~N}\right]$, followed by 1- $n$-butyl-3-methylimidazolium tetrafluoroborate [BMIM] $\left[\mathrm{BF}_{4}\right], 1-n$-butyl-3-methylimidazolium hexafluorophosphate $[\mathrm{BMIM}]\left[\mathrm{PF}_{6}\right]$, and 1,3dimethylimidazolium hexafluorophosphate $[\mathrm{MMIM}]\left[\mathrm{PF}_{6}\right]$. Generally, the effects were concentrationdependent. They also depended on the type of anion and the $n$-alkyl chain length. The comparison between the fish CCO and human HeLa cell lines suggests that CCO cells provide a good biological system for initial toxicity testing of ionic liquids that could replace in vivo bioassays.
\end{abstract}

KEY WORDS: $C C O$ cells, HeLa cells, imidazolium ionic liquids, MTT assay

Ionic liquids are organic salts in liquid state at room temperatures that have recently attracted considerable attention as potential "green" substitutes for conventional volatile solvents, as they do not evaporate and are not flammable (1-2). In addition, ionic liquids are stable thermally, chemically and electrochemically, and can dissolve a wide range of compounds. These desirable properties and almost limitless structural possibilities provide a tremendous potential for application in various fields, such as organic synthesis, biocatalysis, and extraction and separation of biologically important compounds.

However, before their production and use reaches the industrial scale, ionic liquids should be assessed for the impact on human health and environment. One of the useful assessment tools is in vitro testing on cell lines, which can elucidate intracellular, molecular, or physiological mechanisms induced by chemical substances (3). Mammalian cell lines are routinely used for basal cytotoxicity studies (4), while continuous fish cell lines are used in the ecotoxicological assessment of chemicals and environmental samples (5). It is suggested that cytotoxicity tests using dedifferentiated cancer cells provide a quick and convenient first information about the toxic potential of chemical substances (6). The effects of ionic liquids on cell viability have already been reported in wellcharacterised tumour mammalian cell lines such as HeLa (7), CaCo-2 (8), MCF7 (9), and PC12 (10). Investigations of the effects of ionic liquids on the aquatic environment have mostly been based on the evaluation of the growth and survival of different 
aquatic organisms (11-12). Even though fish cell lines are becoming the most important in vitro tool in aquatic ecotoxicology (13), investigations of ionic liquid cytotoxicity in continuous fish cell lines have not been reported yet.

The aim of our study was to assess the cytotoxicity of imidazolium ionic liquids in the ovarian fish cell line CCO and the human tumour cell line HeLa using the MTT cell viability assay.

\section{MATERIALS AND METHODS}

\section{Ionic liquids}

The ionic liquids 1- $n$-butyl-3-methylimidazolium tetrafluoroborate [BMIM] $\left[\mathrm{BF}_{4}\right], 1-n$-butyl-3methylimidazolium hexafluorophosphate [BMIM] $\left[\mathrm{PF}_{6}\right]$, and 1-n-butyl-3-methylimidazolium bis(trifluoromethylsulphonyl)imide, [BMIM] $\left[\mathrm{Tf}_{2} \mathrm{~N}\right]$ used in the experiments were purchased from Acros Organics, USA. 1,3-dimethylimidazolium hexafluorophosphate [MMIM][PF$\left.{ }_{6}\right]$ was synthesised by M. Cvjetko in the Laboratory of Cell Culture Technology and Biotransformations (Zagreb, Croatia). The structures of the tested ionic liquids are shown in Table 1.

\section{Materials}

Dulbecco's modified Eagle's medium (DMEM), phosphate-buffered saline (PBS), and Trypan blue were purchased from Sigma, St. Louis, MO, USA. Heat-inactivated foetal bovine serum (FBS) was purchased from GIBCO, Paisley, Scotland, UK. 3(4,5-dimethylthiazol-2-yl)-2,5-diphenyltetrazolium bromide (MTT) was obtained from Sigma-Aldrich Chemie, Steinheim, Germany. DMSO was purchased from Kemika, Zagreb, Croatia.

\section{Cell lines}

The CCO cell line, derived from the ovaries of Channel catfish (Ictalurus punctatus, Rafinesque, 1818), was purchased from the American Type Culture Collection (ATCC, Manassas, VA, USA; ATCC ${ }^{\circledR}$ number CRL-2772). The HeLa cell line, derived from the human cervical carcinoma, was obtained from the Ruđer Bošković Institute, Zagreb, Croatia. Both cell lines were cultured in $75 \mathrm{~mL}$ flasks in DMEM supplemented with $10 \%$ inactivated FBS and maintained at $5 \% \mathrm{CO}_{2}$. $\mathrm{CCO}$ cells were incubated at $30{ }^{\circ} \mathrm{C}$ and HeLa cells were incubated at $37^{\circ} \mathrm{C}$.

\section{Cell treatment}

Samples of CCO and HeLa cells were taken at the exponential growth phase and counted using the Trypan blue. Cells were then seeded in 24-well plates at a density of $5 \times 10^{4}$ cells $\mathrm{mL}^{-1}$ in $1 \mathrm{~mL}$ of media. Stock solutions of the ionic liquids $\left(1 \mathrm{~mol} \mathrm{~L}^{-1}\right)$ were prepared in the culture medium or DMSO. After $24 \mathrm{~h}$ of cell growth, the medium was replaced with fresh medium containing different concentrations of ionic liquids. Both cell types were exposed to ionic liquids in the concentration range from $0.1 \mathrm{mmol} \mathrm{L}^{-1}$ to $10 \mathrm{mmol} \mathrm{L}^{-1}$; CCO cells for $72 \mathrm{~h}$ and HeLa cells for $48 \mathrm{~h}$. The final DMSO concentration in the medium was $0.1 \%$ for each sample.

\section{Cytotoxicity assay}

The cytotoxicity of ionic liquids was measured using the MTT assay as described by Mosmann (14). The absorbance of purple formazan was measured at $570 \mathrm{~nm}$ using a spectrophotometer (Helios, Thermo Electro Corporation). The results are given as percentages of the control absorbance.

\section{Statistical analysis}

The obtained data are expressed as the mean \pm SEM of three independent experiments performed in triplicate. We used the one-way analysis of variance (ANOVA) with Dunnett's test and set the probability level of $p<0.05$ as statistically significant. The half maximal effective concentration $\left(\mathrm{EC}_{50}\right)$, defined as the concentration of ionic liquid that resulted in $50 \%$ growth inhibition, was calculated from the doseresponse curves using equations of related trend lines for the MTT assay.

\section{RESULTS}

\section{Cytotoxicity of ionic liquids in CCO and HeLa cells}

Figure 1a shows the effects of different $[\mathrm{BMIM}]\left[\mathrm{BF}_{4}\right]$ concentrations on $\mathrm{CCO}$ and HeLa cells, expressed as percentages of viability. The proliferation of CCO cells was not affected by $[\mathrm{BMIM}]\left[\mathrm{BF}_{4}\right]$ at the concentrations of $0.1 \mathrm{mmol} \mathrm{L}^{-1}$ and $0.5 \mathrm{mmol} \mathrm{L}^{-1}$, but in HeLa cells these caused a slight cytotoxic effect. 
a) $[\mathrm{BMIM}]\left[\mathrm{BF}_{4}\right]$

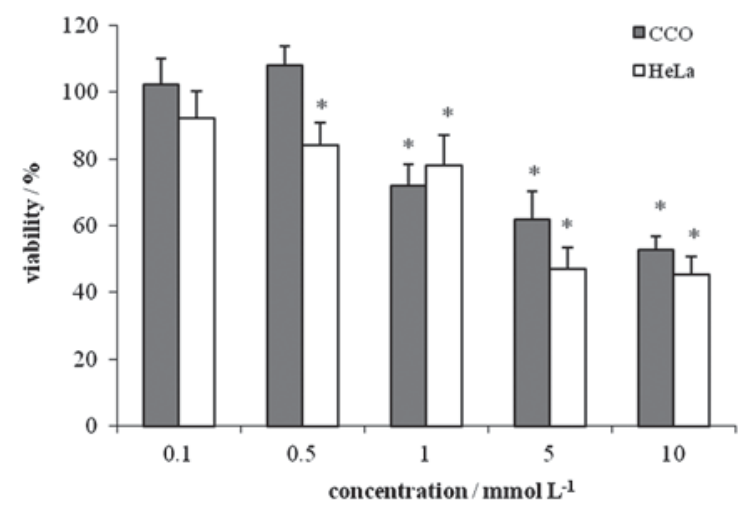

c) $[\mathrm{MMIM}]\left[\mathrm{PF}_{6}\right]$

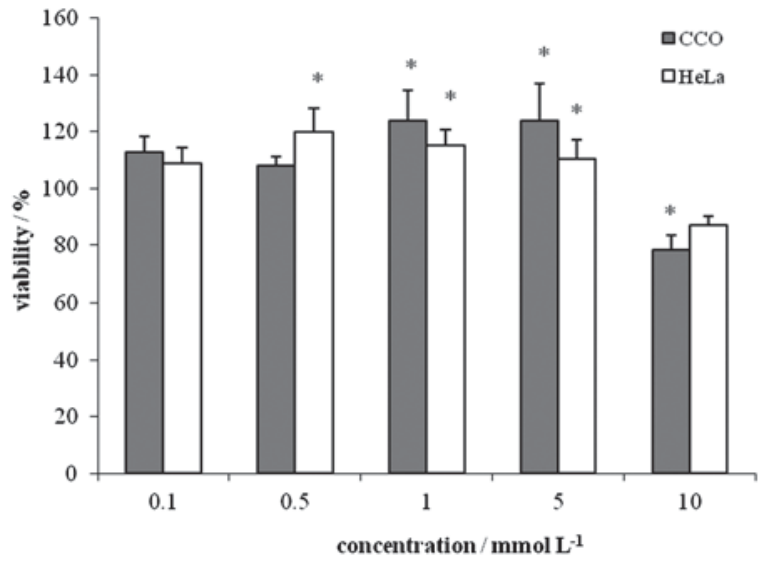

b) $[\mathrm{BMIM}]\left[\mathrm{PF}_{6}\right]$

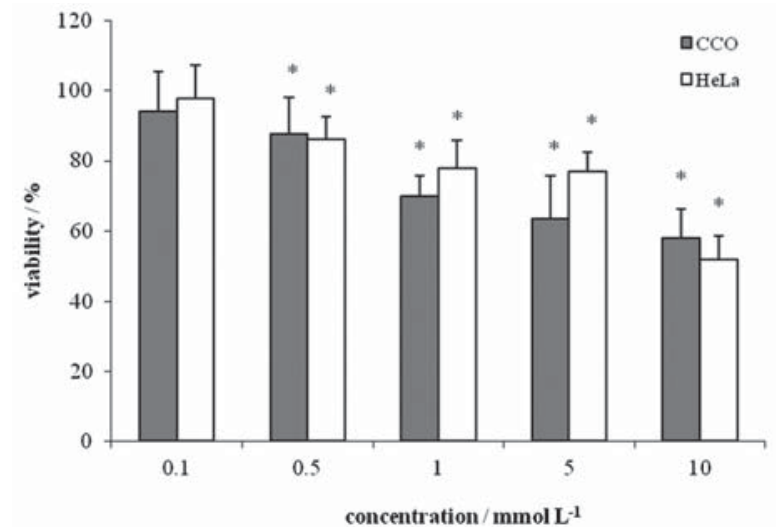

d) $[\mathrm{BMIM}]\left[\mathrm{Tf}_{2} \mathrm{~N}\right]$

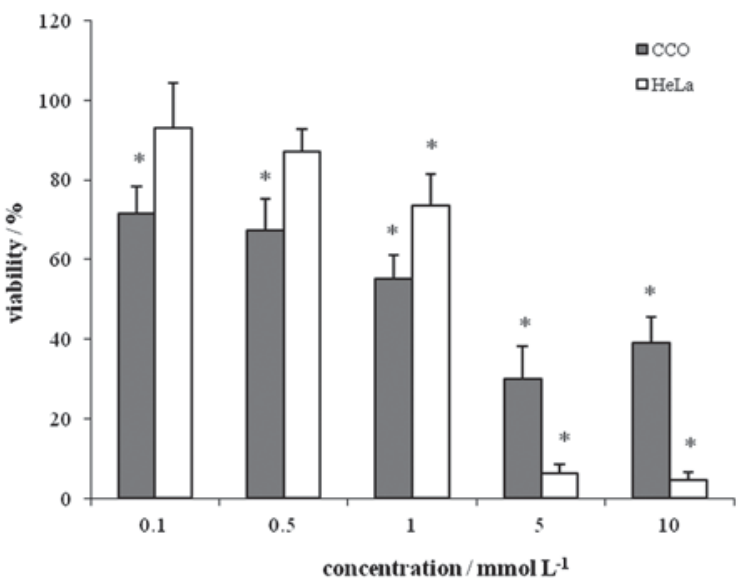

Figure 1 Effects of [BMIM][BF ], [BMIM][PF], [MMIM][PF $]$, and [BMIM][Tf $\left.{ }_{2}\right]$ at different concentrations on CCO and HeLa cell viability. Data expressed as a percentage of unexposed control cells $\pm S E M$ of three replicates for each exposure concentration. ${ }^{*}$ denotes significant difference from control $(p<0.05)$.

Table 1 Ionic liquids used in the study

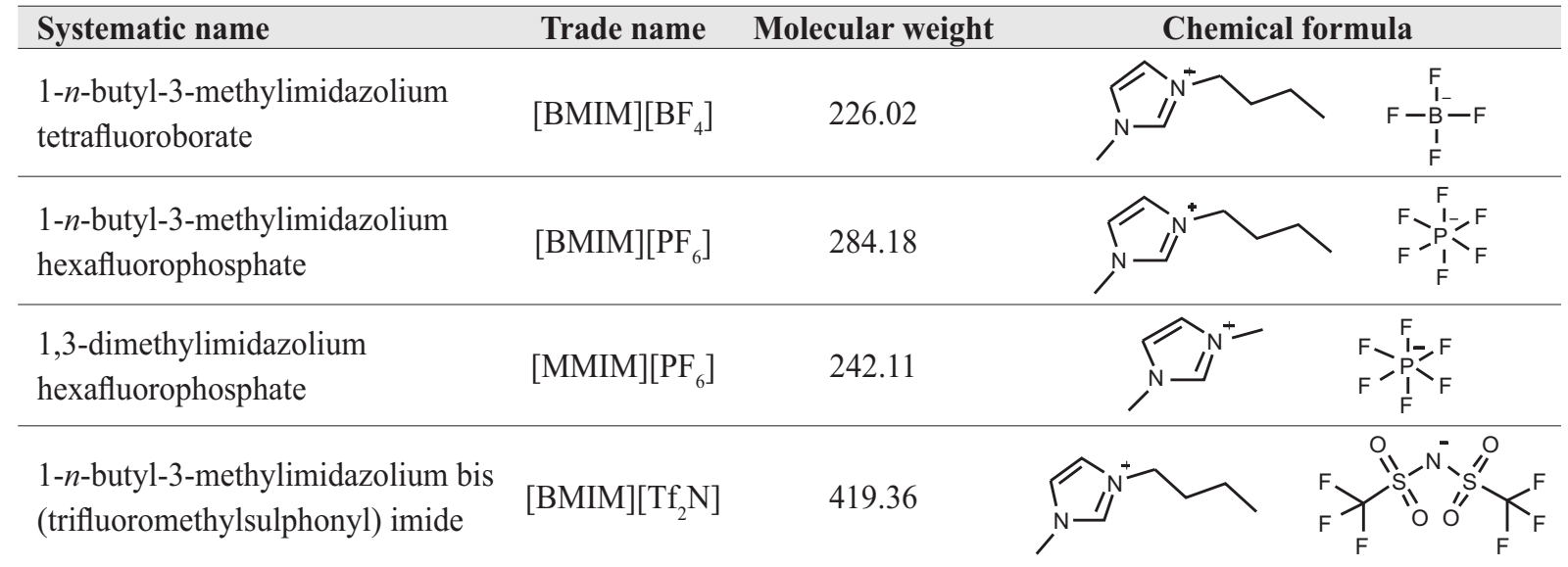

Table $2 E_{50}\left(\mathrm{mmol} \mathrm{L}^{-1}\right)$ of the selected imidazolium ionic liquids in CCO and HeLa cells

\begin{tabular}{lcc}
\hline Ionic liquid & CCO cells & HeLa cells \\
\hline$[\mathrm{BMIM}]\left[\mathrm{Tf}_{2} \mathrm{~N}\right]$ & $3.26 \pm 0.18$ & $3.11 \pm 0.11$ \\
{$[\mathrm{BMIM}]\left[\mathrm{BF}_{4}\right]$} & $5.01 \pm 0.32$ & $4.42 \pm 0.18$ \\
{$[\mathrm{BMIM}]\left[\mathrm{PF}_{6}\right]$} & $10.32 \pm 0.28$ & $11.2 \pm 0.15$ \\
{$[\mathrm{MMIM}]\left[\mathrm{PF}_{6}\right]$} & - & - \\
\hline
\end{tabular}


Higher concentrations of $[\mathrm{BMIM}]\left[\mathrm{BF}_{4}\right]\left(1 \mathrm{mmol} \mathrm{L}^{-1}\right.$ to $\left.10 \mathrm{mmol} \mathrm{L}^{-1}\right)$ induced a significant cytotoxic effect in both cell lines. Survival rates decreased as $[\mathrm{BMIM}]\left[\mathrm{BF}_{4}\right]$ concentrations increased.

Figure $1 \mathrm{~b}$ shows viability of $\mathrm{CCO}$ and HeLa cells exposed to different $[\mathrm{BMIM}]\left[\mathrm{PF}_{6}\right]$ concentrations $\left(0.1 \mathrm{mmol} \mathrm{L}^{-1}\right.$ to $\left.10 \mathrm{mmol} \mathrm{L}^{-1}\right)$. At $0.1 \mathrm{mmol} \mathrm{L}^{-1}$, [BMIM] $\left[\mathrm{PF}_{6}\right]$ did not cause significant cytotoxic effects in either cell line. Significant cytotoxic effects in both $\mathrm{CCO}$ and HeLa cells started at $0.5 \mathrm{mmol} \mathrm{L}^{-1}$ and increased in the dose-dependent manner.

Exposure to [MMIM] $\left[\mathrm{PF}_{6}\right]$ (Figure 1c) led to significant cytotoxic effects only in CCO cells at $10 \mathrm{mmol} \mathrm{L}^{-1}$. At lower concentrations, [MMIM] $\left.\mathrm{PF}_{6}\right]$ in fact significantly improved cell viability in both cell lines; in HeLa cells at doses up to and including $5 \mathrm{mmol} \mathrm{L}^{-1}$ and in CCO cells at $1 \mathrm{mmol} \mathrm{L}^{-1}$ and $5 \mathrm{mmol} \mathrm{L}^{-1}$.

Exposure to [BMIM] $\left[\mathrm{Tf}_{2} \mathrm{~N}\right]$ produced significant cytotoxic effects in $\mathrm{CCO}$ cells at all tested concentrations (Figure 1d). In contrast, significant cytotoxicity in HeLa cells was observed only at higher concentrations $\left(1 \mathrm{mmol} \mathrm{L}^{-1}\right.$ to $\left.10 \mathrm{mmol} \mathrm{L}^{-1}\right)$. In addition, at $5 \mathrm{mmol} \mathrm{L}^{-1}$ and $10 \mathrm{mmol} \mathrm{L}^{-1}$ this effect was much stronger in HeLa cells (95\%) than in CCO cells $(65 \%)$.

\section{Comparison of cytotoxicity in $\mathrm{CCO}$ and HeLa cells}

Table 2 shows the half maximal effective concentrations $\left(\mathrm{EC}_{50}\right)$ for selected ionic liquids in $\mathrm{CCO}$ and HeLa cells, that were calculated from cell viability data. The exception is $[\mathrm{MMIM}]\left[\mathrm{PF}_{6}\right]$ which could not decrease cell viability below $80 \%$ in CCO cells and $85 \%$ in HeLa cells, even at the highest tested concentration. The lowest $\mathrm{EC}_{50}$ was calculated for $[\mathrm{BMIM}]\left[\mathrm{Tf}_{2} \mathrm{~N}\right]$ in both cell lines, followed by $[\mathrm{BMIM}]\left[\mathrm{BF}_{4}\right]$ and $[\mathrm{BMIM}]\left[\mathrm{PF}_{6}\right]$.

\section{DISCUSSION}

Even though ionic liquids are originally considered "green solvents", recent studies on their ecotoxicity and degradability has shown that some are not as environmentally friendly as others (15). This calls for a careful and critical assessment that should be able to predict their effects on human health and environment.

Our study compared the cytotoxic effects and $\mathrm{EC}_{50}$ of four imidazolium ionic liquids in fish $\mathrm{CCO}$ and human tumour HeLa cells. [BMIM] $\left[\mathrm{BF}_{4}\right]$ had about half the $\mathrm{EC}_{50}\left[(5.01 \pm 0.32) \mathrm{mmol} \mathrm{L}^{-1}\right.$ in CCO cells and (4.42 \pm 0.18$) \mathrm{mmol} \mathrm{L}^{-1}$ in HeLa cells] of [BMIM] $\left[\mathrm{PF}_{6}\right]$ [(10.32 \pm 0.28$) \mathrm{mmol} \mathrm{L}^{-1}$ for CCO cells and (11.2 \pm 0.15$) \mathrm{mmol} \mathrm{L}^{-1}$ for HeLa cells]. Similar results for HeLa cells have also been reported by Stepnowski et al. (7) and Wang et al. (16).

$\mathrm{EC}_{50}$ did not differ much between $\mathrm{CCO}$ and $\mathrm{HeLa}$ cells, and since there is no available data on the toxicity of ionic liquids in fish cells, this finding may be relevant for the comparison of cytotoxicity data between fish and mammalian cell lines.

We also observed a significant stimulatory effect on $\mathrm{CCO}$ and $\mathrm{HeLa}$ cell viability by $[\mathrm{MMIM}]\left[\mathrm{PF}_{6}\right]$ at the concentrations of $0.5 \mathrm{mmol} \mathrm{L}^{-1}$ to $5 \mathrm{mmol} \mathrm{L}^{-1}$. This phenomenon is known as chemical hormesis, which is characterised by low-dose stimulation and high-dose inhibition (17). A similar hormetic effect of 1-n-octylmethylimidazolium tetrafluoroborate $\left[\mathrm{C}_{8} \mathrm{MIM}\right]\left[\mathrm{BF}_{4}\right]$ was observed in IPC-81 leukaemia cells (18) and of 1- $n$-butyl-3-ethylimidazolium tetrafluoroborate [BEIM] $\left[\mathrm{BF}_{4}\right]$ in HeLa cells (7).

It seems that $n$-alkyl chain length correlates with toxicity, as $[\mathrm{BMIM}]\left[\mathrm{PF}_{6}\right]$ was more toxic in both cell lines than $[\mathrm{MMIM}]\left[\mathrm{PF}_{6}\right]$, which is consistent with the results reported by Ranke et al. (18).

It also seems that cytotoxicity may be related to the anion; the lowest $\mathrm{EC}_{50}$ in both cell lines was found for $\left[\mathrm{Tf}_{2} \mathrm{~N}\right]$. Kumar et al. (9) showed that the $\left[\mathrm{Tf}_{2} \mathrm{~N}\right]$ anion was more toxic in MCF7 cells than the bromide anion, and this toxicity could be associated with hydrolytic cleavage that resulted in the formation of free fluoride ions (19).

HeLa cells showed higher sensitivity when exposed to $5 \mathrm{mmol} \mathrm{L}^{-1}$ and $10 \mathrm{mmol} \mathrm{L}^{-1}$ of $[\mathrm{BMIM}]\left[\mathrm{Tf}_{2} \mathrm{~N}\right]$ than the $\mathrm{CCO}$ cells. This might point to HeLa-specific mechanisms of [BMIM] $\left[\mathrm{Tf}_{2} \mathrm{~N}\right.$ ] action. Similarly specific mechanisms of action have been observed for other cell lines and imidazolium liquids (18).

Castaño et al. (20) compared the sensitivity of in vitro basal cytotoxicity tests (MTT assay) in fish and mammalian cell lines. These cells showed similar sensitivity when exposed to a range of chemicals. Although our results with $\mathrm{CCO}$ and HeLa cells are in agreement with this study, future in vitro cytotoxicity studies should include more cell lines to provide a more comprehensive information about the effects of ionic liquids in specific mammalian and fish cell lines. 
In conclusion, our results obtained with $\mathrm{CCO}$ and HeLa cell lines show that the toxicity of the selected ionic liquids depends on the dose, anion type, and $n$-alkyl chain length. This has been the first study to assess the cytotoxicity of ionic liquids in fish $\mathrm{CCO}$ cells and it suggests that fish cell lines could be a good biological system for initial toxicity testing of ionic liquids that could replace in vivo fish bioassays. However, future studies on other fish cell lines should answer if differences between fish species and tissues/ organs could affect toxicity data and their interpretation.

\section{Acknowledgements}

This work was supported by the Ministry of Science, Education and Sports of the Republic of Croatia (grants no. 058-0582184-2414 and 058-0582261-2256).

\section{REFERENCES}

1. Suarez PAZ, Einloft S, Dullius JEL, de Souza RF, Dupont J. Synthesis and physical-chemical properties of ionic liquids based on 1- $n$-butyl-3-methylimidazolium cation. J Chim Phys 1998;95:1626-39.

2. Dupont J, de Souza RF, Suarez PAZ. Ionic liquid (molten salt) phase organometallic catalysis. Chem Rev 2002;102:3667-91.

3. Kniewald J, Kmetič I, Gaurina Srček V, Kniewald Z. Alternative models for toxicity testing of xenobiotics. Arh Hig Rada Toksikol 2005;56:195-204.

4. Ekwall B. The basal cytotoxicity concept. In: Goldberg AM, Van Zupthen LFM, editors. Alternative methods in toxicology and the life sciences. The world congress on alternatives and animal use in the life sciences: education, researches, testing. Vol 11. New York: Mary Ann Liebert; 1995. p. 721-5.

5. Fent K. Fish cell lines as versatile tools in ecotoxicology: assessement of cytotoxicity, cytochrome P4501A induction potential and estrogenic activity of chemicals and enviromental samples. Toxicol in Vitro 2001;15:477-88.

6. Ranke J, Müller A, Bottin-Weber U, Stock F, Stolte S, Arning J, Störman R, Jastroff B. Lipophilicity parameters for ionic liquid cations and their correlation to in vitro cytotoxicity. Ecotoxicol Environ Saf 2007;67:430-8.

7. Stepnowski P, Skladanowski AS, Ludwiczak A, Laczyńska E. Evaluating the cytotoxicity of ionic liquids using human cell line HeLa. Hum Exp Toxicol 2004;23:513-7.
8. Frade R, Rosatella A, Marques C, Branco L, Kulkarni P, Mateus N, Afonso C, Duarte C. Toxicological evaluation on human colon carcinoma cell line $(\mathrm{CaCo}-2)$ of ionic liquids based on imidazolium, guanidinium, ammonium, phosphonium, pyridinium and pyrrolidinium cations. Green Chem 2009;11:1160-5.

9. Kumar A, Papaïconomou N, Lee J, Salminen J, Clark D, Prausnitz J. In Vitro cytotoxicities of ionic liquids: Effect of cation rings, functional groups, and anions. Environ Toxicol 2009;24:388-95.

10. Samori C, Malferrari D, Valbonesi P, Montecavalli A, Moretti F, Galletti P, Sartor G, Tagliavini E, Fabbri E, Pasteris A. Introduction of oxygenated side chain into imidazolium ionic liquids: Evaluation of the effects at different biological organization levels. Ecotoxicol Environ Saf 2010;73:145664.

11. Latała A, Stepnowski P, Nędzi M, Mrozik W. Marine toxicity assessment of imidazolium ionic liquids: acute effects on the Baltic algae Oocystis submarina and Cyclotella meneghiniana. Aquat Toxicol 2005;73:91-8.

12. Cho CW, Pham TPT, Jeon YC, Vijayaraghavan K, Choe WS, Yun YS. Toxicity of imidazolium salt with anion bromide to a phytoplankton Selenastrum capricornutum: effect of alkyl-chain length. Chemosphere 2007;69:10037.

13. Schrimer K. Proposal to improve vertebrate cell cultures to establish them as the substitutes for the regulatory testing of chemicals and effluents using fish. Toxicology 2006;224:163-83.

14. Mosmann T. Rapid colorimetric assay for cellular growth and survival, application to proliferation and cytotoxic assays. J Immunol Methods 1983;65:55-63.

15. Zhu S, Chen R, Wu Y, Chen Q, Zhang X, Yu Z. A mini-review on greenness of ionic liquids. Chem Bichem Eng $Q$ 2009;23:207-11.

16. Wang XF, Ohlin AC, Lu Q, Fei Z, Hu J, Dyson PJ. Cytotoxicity of ionic liquids and precursor compounds towards human cell line HeLa. Green Chem 2007;9:11917.

17. Calabrese EJ, Baldwin AJ. Hormesis: the dose-response revolution. Annu Rev Pharmacol Toxicol 2003;43:175-97.

18. Ranke J, Mölter K, Stock F, Bottin-Weber U, Poczobutt J, Hoffmann J, Ondruschka B, Filser J, Jastorff B. Biological effects of imidazolium ionic liquids with varying chain lengths in acute Vibrio fischeri and WST-1 cell viability assays. Ecotoxicol Environ Saf 2004;58:396-404.

19. Stolte S, Arning A, Bottin-Weber U, Matzke M, Stock F, Thiele K, Uerdingen M, Welz-Biermann U, Jastroff B, Ranke J. Anion effects on the cytotoxicity of ionic liquids. Green Chem 2006;8:621-9.

20. Castaño A, Gómez-Lechón MJ. Comparison of basal cytotoxicity data between mammalian and fish cell lines: a literature survey. Toxicol in Vitro 2005;19:695-705. 


\section{Sažetak}

\section{CITOTOKSIČNI UČINCI IONSKIH TEKUĆINA NA STANIČNIM LINIJAMA RIBA I LJUDI}

S obzirom na širok raspon primjena ionskih tekućina, prethodno je potrebno ispitati njihovu toksičnost $i$ mogući utjecaj na zdravlje ljudi i okoliš. U ovom radu ispitana je citotoksičnost odabranih imidazolijevih ionskih tekućina na stanicama ovarija riba CCO i ljudskoj tumorskoj staničnoj liniji HeLa primjenom MTT-metode. Izlaganje stanica različitim koncentracijama ionskih tekućina $\left[(0,1\right.$ do 10$\left.) \mathrm{mmol} \mathrm{L}^{-1}\right]$ rezultiralo je uglavnom citotoksičnim učincima ovisnima o koncentracijama ionske tekućine. Na temelju dobivenih vrijednosti $\mathrm{EC}_{50}$ najtoksičnija ionska tekućina je 1-n-butil-3-metilimidazolijev bis(trifluorome tilsulfonil)imid [BMIM][Tf2N], zatim 1- $n$-butil-3-metilimidazolijev tetrafluoroborat [BMIM][BF4],1-nbutil-3-metilimidazolijev heksafluorofosfat [BMIM][PF6] i 1,3-dimetilimidazolijev heksafluorofosfat [MMIM][PF6]. Općenito, toksičnost je bila ovisna o koncentraciji, tipu aniona i duljini $n$-alkilnog lanca. Nakon usporedbe rezultata toksičnosti na CCO i HeLa-stanicama smatramo da CCO-stanice mogu biti dobar biološki sustav za početna ispitivanja toksičnosti ionskih tekućina u cilju zamjene in vivo testova na ribama.

KLJUČNE RIJEČI: CCO-stanice, HeLa-stanice, imidazolijeve ionske tekućine, MTT-metoda

\section{CORRESPONDING AUTHOR:}

\section{Višnja Gaurina Srček, PhD}

Laboratory for Cell Culture Technology and

Biotransformations

Faculty of Food Technology and Biotechnology

Pierottijeva 6, Zagreb, Croatia

E-mail:vgaurina@pbf.hr 